\title{
Regulation of blood glucose by administration of allogenic bone marrow derived mesenchymal stem cells into diabetic rats through modulating regeneration of both $\alpha$ and $B$ islet cells
}

\author{
Fan-Biao Meng ${ }^{1,2,3,4}$, Xiao-Yu Liu' ${ }^{1}$, Hong-Tu Li ${ }^{1}$, Xi-Ning Pang ${ }^{1 *}$ and Gang Li ${ }^{1,2,3,4^{*}}$ \\ *Correspondence: gangli@cuhk.edu.hk and pxining@yahoo.com \\ 'Department of Stem Cells and Regenerative Medicine, Key Laboratory of Cell Biology of ChinaMinistry of Public Health, \\ China Medical University, Shen-Yang, PR China. \\ 2Department of Orthopaedics \& Traumatology, The Chinese University of Hong Kong, Prince of Wales Hospital, \\ Shatin, Hong Kong, PR China. \\ ${ }^{3}$ Stem Cell and Regeneration Theme, School of Biomedical Sciences and Li Ka Shing Institute of Health Sciences, \\ The Chinese University of Hong Kong, Prince of Wales Hospital, Shatin, Hong Kong, PR China. \\ ${ }^{4}$ The Chinese University Shenzhen Research Institute, Shenzhen, Guangdong Province, PR China.
}

\begin{abstract}
Background: Transplanting bone marrow derived mesenchymal stem cells(MSCs) have positive effects in treating many disease conditions including diabetes. To investigate the effects of systemic administration of MSCs on blood glucose changes, we studied the changes of islet $\beta$ and $\alpha$ cellsin STZ-induced diabetic rats following systemic MSCs administration.

Methods: MSCs were isolated from rat bone marrow, characterized, expanded in vitro and labeled with GFP by lentivirus transfection. $2 \times 10^{6}$ MSCs were injected into the rats via caudal vein at 10 days following STZ administration. The fasting glucose serum levels were measured following the treatment. Animals were terminated at day 21 and 35 following STZ injection. The insulin, $\mathrm{Pdx} 1$, glucagon and somatoatatin expressing cells in the pancreatic sections were quantified by immunofluorescence methods.

Results: We found that the blood glucose levels in the rats receiving MSCs were significantly reduced compared to the control group at day 21 following STZ treatment, and it reached to the similar high glucose level again at day 28 . The injected MSCs were found in the pancreatic tissues, and the islets in the treatment group were partially restored in contrast to the control group. There were greater numbers of Pdx1+Insulin-cells in the MSCs treatment group, suggesting the ongoing regeneration of islet. The number of a cellswas significantly higher in the MSCs-treated group and untreated control group than that of normal group, which may associate with higher blood glucose level in later stage of MSCs administration. In addition, MSCs were co-cultured with the isolated rat islets and islet-like cells (INS1) in vitro and we found that the expression of Cdk4 was up-regulated in the islets when co-cultured with MSCs.

Conclusions: We concluded that transplanting allogenic MSCs may promote the regeneration of the injured islets, but the underlying mechanisms need further investigation.
\end{abstract}

Keywords: Mesenchymal stem cells, islet regeneration, islet $\alpha$ and $\beta$ cells, cdk4

\section{Background}

Bone marrow derived mesenchymal stem cells (MSCs) are adult stem cells, with high proliferative potential and ability to differentiate into a variety of cell types [1]. MSCs have been demonstrated to support long-term growth of HSCs hematopoietic stem cells and maintain hematopoietic and skeletal homeostasis [2]. Previous studies showed MSCs transplantation resulted in improvement of diabetes conditions, such as reducing blood glucose levels [3-5], partially because of the immunosuppressive effects of MSCs on T cells, increasing pancreatic islet $\beta$ cell mass, preventing of $\beta$ cell death [6] and promoting islet regeneration [7]. However, the effects of MSCs transplantation on islet cells are still not well understood. Islet is mainly consisted of $\alpha, \beta$, $\delta$ cells, which are responsible for secreting of insulin, glucagons and somatostatin respectively [8]. Insulin reduces the blood glucose, whereas glucagon has the opposite role of increasing blood glucose. It is known that type I diabetes is due to thereduction of absolute quantities of islets. Understanding the effects of MSCs transplantation on islet cells will help to develop more effective treatment strategies.

Islet cells were differentiated from endocrine progenitors, the $\mathrm{Pdx} 1^{+}$pancreatic progenitors $[9,10]$. Knocking out $\mathrm{Pdx} 1$ in mouse resulted in complete loss of whole pancreas including islets [9]. Pdx1 expression became restrictive in islet $\beta$ cells during developmental process [11]. Islet $\beta$ cells neogenesis from duct cells are accompanied by the re-activation of Pdx 1 in the injured tissues [12]. A substantial work has been done to elucidate the mechanism of the islet proliferation and 
Meng et al. Journal of Diabetes Research and Clinical Metabolism 2013,

regeneration. MSCs may exert positive effects by promoting the proliferation of islet $\beta$ cells. Hess and his colleagues found that bone marrow MSCs could stimulate host pancreatic regeneration rather than direct trans-differentiation into insulin secreting cells [13].

As one of cell cycle regulators, cyclin kinase 4 (Cdk4) plays a key role in the proliferation of islet $[14,15]$. Expression of the $16^{\mathrm{INK} 4 \mathrm{a}}$, a potent inhibitor of Cdk4 resulted in declining islet regeneration [16]. Cdk4 can be used as an indicator for islet regeneration. In the present study, we administrated GFP-labeled MSCs into the diabetic rats and found that injection of MSCs could reduce blood glucose level for a period and there were evidence of islet regeneration with increased expression of Cdk4 in pancreatic tissues. The result of our study indicated that administration of allogenic MSCs in diabetic rats could reduce blood glucose, through regulating islet $\alpha$ and $\beta$ cells proliferation. However, the optimal dose and time of MSCs administration needs further careful investigation.

\section{Methods \\ Subjects}

Adult wistar rats (male, 200-250 g) were used for MSCs isolation and diabetic model establishment. The animal experimental protocols were approved by the Animal Care and Use Committee of China Medical University, Shenyang, China and The Chinese University of Hong Kong, Hong Kong.

\section{Study design}

Rats $(n=30)$ were fed routinely, then fasted for 12 hours, blood was taken from the caudal veins, and the blood glucose was monitored using semi-automatic biochemical analyzer (Vital Science). To establish diabetic rat model, Streptozotocin (STZ, Sigma) prepared in $0.1 \mathrm{M}$ citrate buffer $(\mathrm{pH} 4.5)$ was injected intraperitoneally at the dose $50 \mathrm{mg} / \mathrm{kg}$ as described previously [17]. Streptozotocin could induce diabetes within 3 days by destroying the $\beta$ cells [18]. The blood glucose was then measured at 5 and 7 days after injection to confirm the onset of hyperglycemia. At day 10 following STZ injection, the GFP-MSCs ( $2 \times 10^{6}$ per rat) were injected via caudal veins. The diabetic syndromes were observed, and the fasting blood glucose level was monitored at day 21, 28, 35 following STZ injection.

\section{Isolation and culture of bone marrow MSCs}

MSCs were isolated from male adult wistar rats as previously described. In brief, the rats were terminated, and the tibias and femurs were removed aseptically. Bone marrow were collectedby density gradient centrifugation (Histopaque 1077, Sigma) and cultured in LG-DMEM (Gibco) and $10 \% \mathrm{FCS}$ (Hyclone), $5 \% \mathrm{CO}_{2}$ at $37^{\circ} \mathrm{C}$. The non-adherent cells were discarded after 24 hours. Fresh media werereplenished every three days. MSCs surface markers such as CD14(-), CD34 $(-), C D 44(+), C D 45(-), C D 73(+), C D 90(+)$ were confirmed by flowcytometry.

\section{GFP labeling of MSCs}

MSCs were labeled with GFP expressing gene by lentivirus transfection as previously described [19]. In brief, pGCL-GFP, pHelper 1.0 and pHelper 2.0 plasmids were cotransfected into 293T cells by Lipofectamine 2000 (Invitrogen). The supernatantcontaining lentivirus was harvested $48 \mathrm{~h}$ and $72 \mathrm{~h}$ after transfection andconcentrated by centrifugal filter (Centricon Plus-20, Millipore) following manufacturer instructions. Lentivirus titer was determined by quantifying GFP-expressing cells $48 \mathrm{~h}$ after transfection of 293T cell with serial diluted concentration. For transduction, $1 \times 10^{5} \mathrm{MSCs}$ were seeded into 6-well plate and incubated with lentivirusand $8 \mu \mathrm{g} / \mathrm{mL}$ polybrene in the incubator for $24 \mathrm{~h}$.

\section{Immunocytochemistry and islet area measurement} Rats were sacrificed at day 21 and day 35 following STZ injection. Pancreas were dissected and fixed with $4 \%$ paraformaldehyde. Frozen sections $(8 \mu \mathrm{m})$ of pancreas were blocked with 5\% BSA for 1 hour, and incubated with the primary antibodies overnight at $4^{\circ} \mathrm{C}$. After washing, the sections were then incubated with secondary antibodies at room temperature for 1 hour. Counterstained with DAPI, sections were observed under the fluorescence microscope (Olympus BX51). Primary antibodies were mouseanti-insulin (dilution 1:200, Santa Cruz, USA), rabbit anti-insulin (dilution 1:200, Santa Cruz), mouse anti-somatostatin (1:200 dilution, Santa Cruz), rabbit anti-Glucagon (1:200 dilution, Santa Cruz) and rabbit anti-Pdx1 (1:1000 dilution, Abcam). The insulin positive cells areas from the sections were randomly selected and measured using the software Image Pro-plus 6.0. The statistical analysis for significance was done with Students t-test; $p<0.05$ was considered statistically significance.

\section{Isolation and culture of rat islets}

The rat islet isolation procedure was followed as previously reported [20]. Briefly, the common bile duct was isolated and injected withcollegenase $P$ (Roche). The pancreas were isolated and incubatedat 37 for $15 \mathrm{~min}$. The digested tissues werere-suspended in histopaque 1077 (Sigma) and overlayed using Hanks solution and centrifuged at $1750 \mathrm{~g} 20 \mathrm{~min}$. The islets at the interface were collected after centrifugation and cultured in 10\% FBS 1640 medium.

\section{Co-culture of islets and MSCs}

The fourth passage MSCs were plated at the density of $4 \times 10^{4}$ per well in six-well plastic culture plates, supplemented with $3 \mathrm{ml} 10 \%$ FBS in 1640 medium. The cells became adherent after 6 hours and expanded to monolayer. The medium was changed to the mixture of LG-DMEM and 1640 equally containing 10\% FBS after 3 days. Simultaneously, rat islets were inoculated in the insert (BD) and subsequently placed in the well with MSCs at the bottom. 

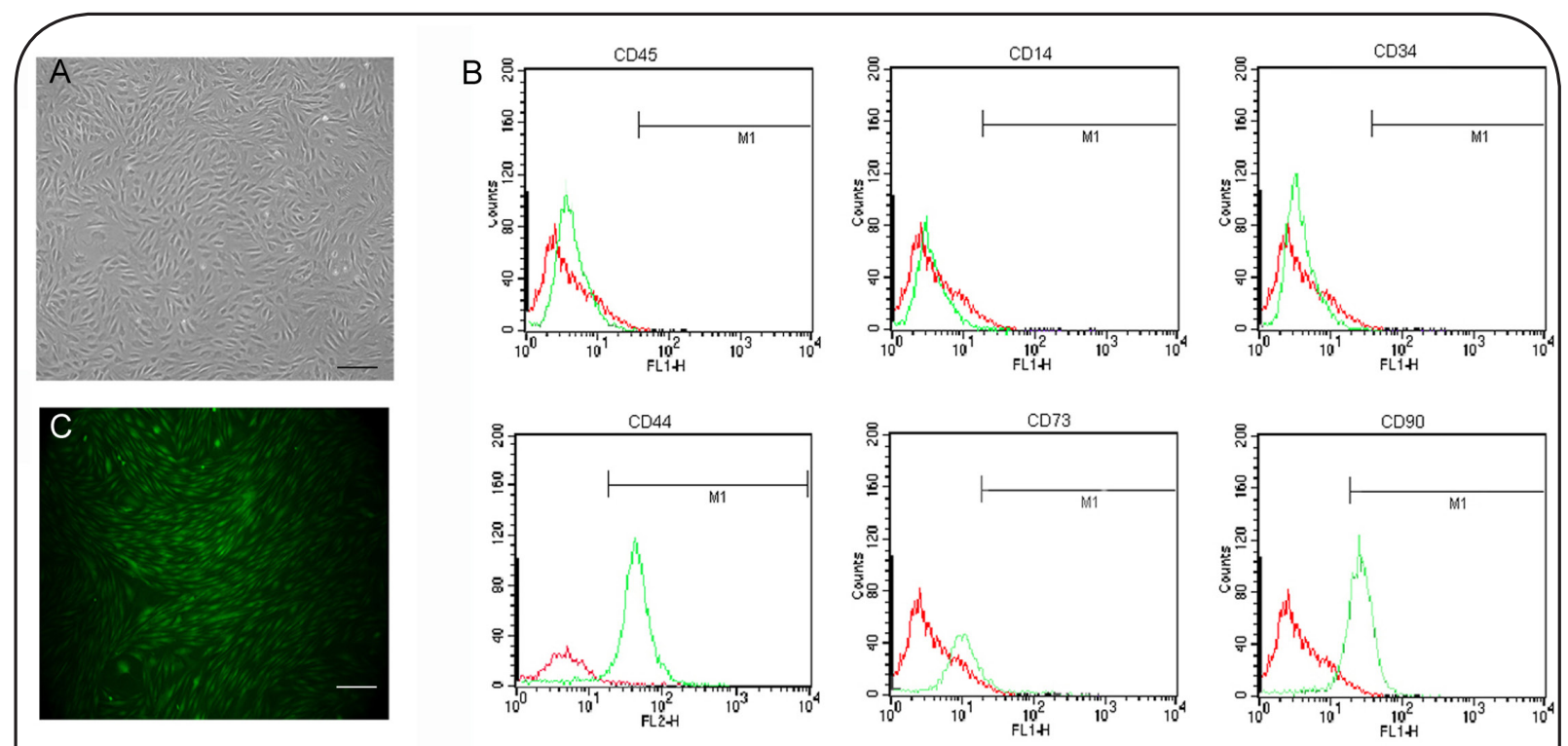

Figure 1. A. MSCs was cultured from rat bone marrow and appeared to be fibroblast like.

B. MSCs surface CD markers were confirmed asCD45(-), CD34(-), CD14(-), CD44(+), CD73(+), CD90(+).

Green curve represents corresponding antibody; Red curve represents isotype control.

C. GFP was used to label MSCs by lentivirus transfection with spindle morphology on confluence. Scale bar, $100 \mu \mathrm{m}$.

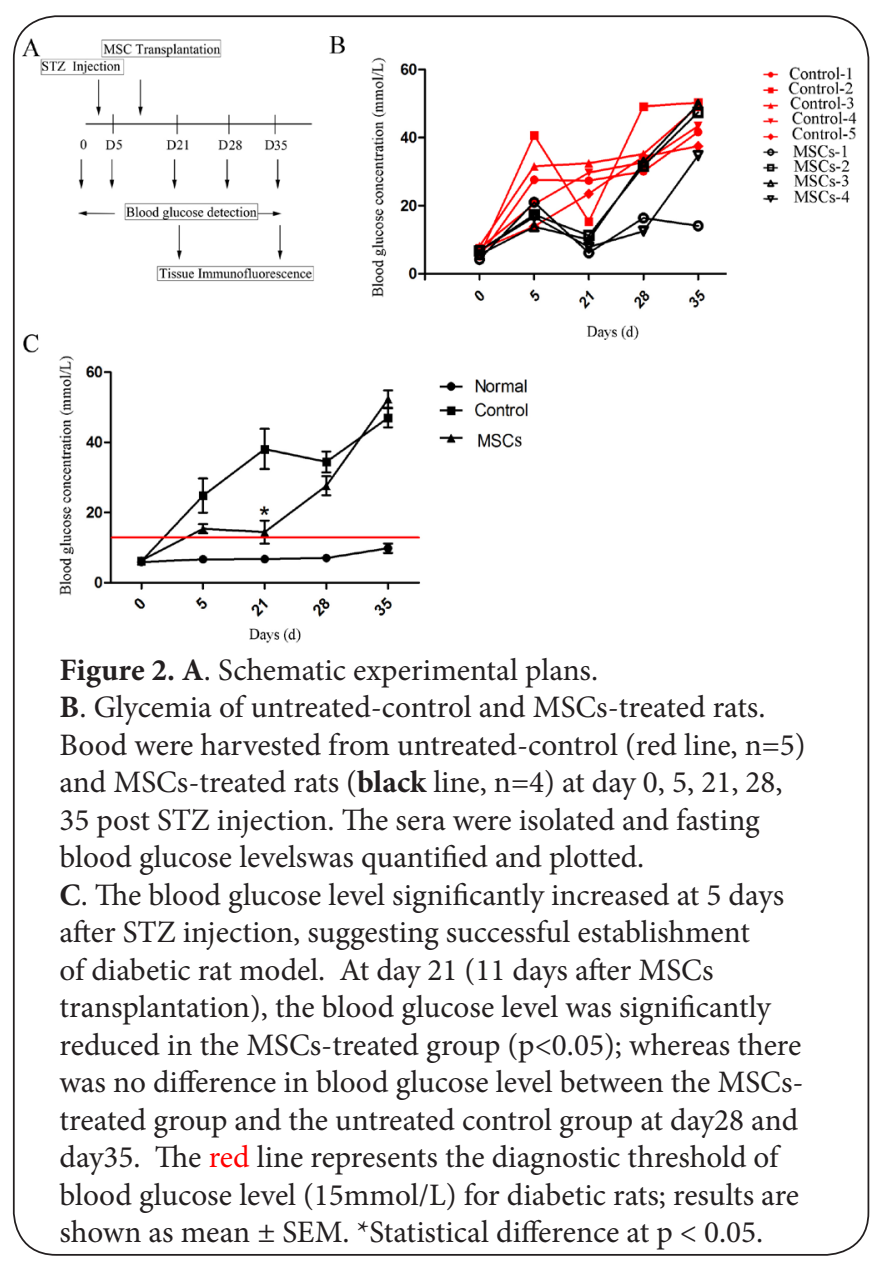

\section{Quantitative PCR of Cdk4}

Islets co-cultured with MSCs for 5 days were harvested. Total RNA of islet and INS1 rat insulinoma cell line (CCTCC, China Center for Type Culture Collection) was then extracted using the Trizol reagent (Invitrogen). Complementary DNA (cDNA) was synthesized by reverse transcription by Moloney Murine Leukemia Virus Reverse Transcriptase (M-MLV RT, Promega). Quantitative PCR was performed to using SYBRPremix Ex Taq (Takara) to examine the expression of Cdk4 (5'-ACAGCTACCAGATGGCCCTCAC-3') according to the manufacturer's instructions. The relative expression of Cdk4 wasanalyzed by ddCt method by normalizing toendogenous GAPDH.

\section{Results}

\section{Isolation, identification and transfectionof MSCs}

MSCs isolated from rat bone marrow presented fibroblast like morphology and proliferated fast (Figure 1A). Passage 3 or 4 MSCs were used for GFP labeling by lentivirus transfection and MSCs were high efficiently labeled with GFP (Figure 1B). Transfection did not alert cell morphology of MSCs. The cell surface markers were examined by flowcytometery and confirmed that the expression of CD45, CD34, CD14 was negative, whereas the expression of CD44, CD73 and CD90 was positive (Figure 1C).

\section{Changes of blood glucose levelfollowing MSCs administration}

The detailed experimental procedures are highlighted in Figure 2A. For STZ-induced diabetic rat model, when the 
A

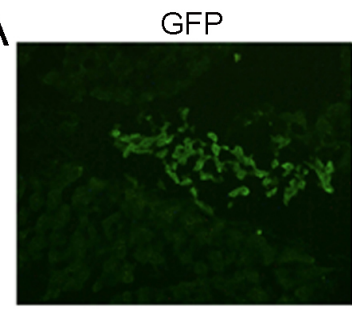

B

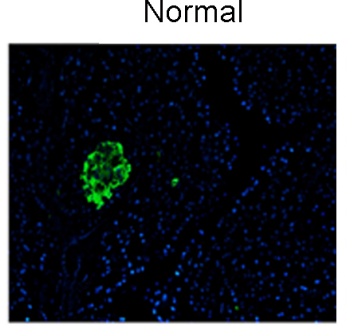

C

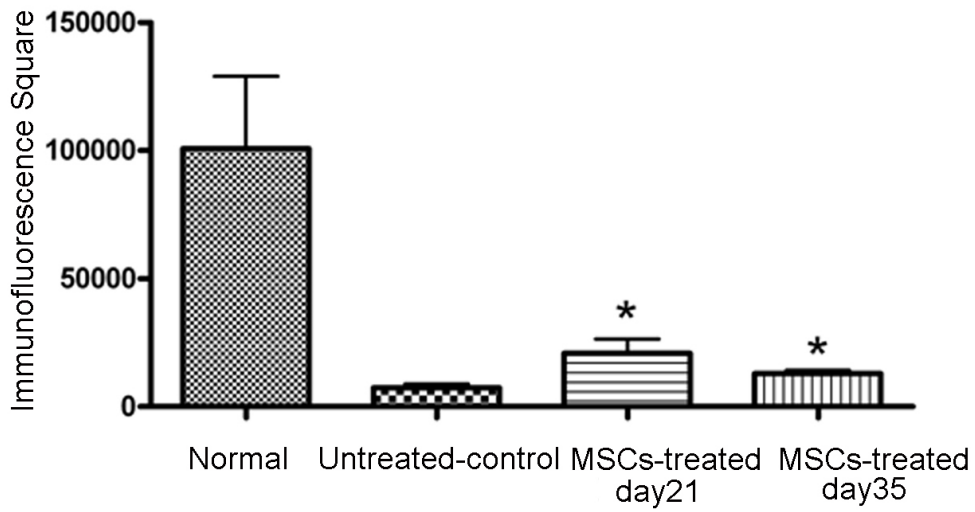

Figure 3. Immunofluorescence examination of pancreatic sections. A.TheGFP-MSCs hadengrafted in the pancreas of MSCs-treated animals. Green color represents the transplanted MSCs.

B. Immunofluorescence of insulin producingcells in the pancreas of normal, untreated control and MSCs-treated animals. The islets in the MSCs-treated group were repaired partially compared to the untreated control group with dispersed insulin positive cells distribution.

C. The areas representing insulin positive cells in the normal, untreated control and MSCs-treated groups were quantified. There was a significant increase of insulin positive cells in the MSCs-treated group at day 21 and day 35 compared to the untreated control group. There was no difference in the numbers of insulin positive in the MSCs-treated group between day 21 and day 35.Scale bar, $100 \mu \mathrm{m}$. ${ }^{\star}$ Statistical difference at $\mathrm{p}<0.05$. blood glucose levelwas greater than that of normal rat (e.g. $>15 \mathrm{mmol} / \mathrm{L}$ ) for two times, the rats were regarded as diabetes [17]. All STZ given rats were considered diabetic at day 10 , and the GFP-MSCs were then injected at day 10. Blood glucose level was monitored weeklythereafter till termination at day 21 and 35 following STZ injection. The fasting blood glucose level of each rats from untreated-control and MSCs-treated group were ploted (Figure 2B). We found that the blood glucose levelin the MSCs treatment group was significantly lower than that of theuntreated control group at 11 days following MSCs injection (day 21 after STZ injection), although it was still higher than that of the normal level. However, the blood glucose level increased againat day 28 following STZ injection, with no significant difference between the MSCs treated and non-treated control group (Figure 2C).

Injected MSCs engrafted the pancreas and promoted the regeneration of islets

To investigate the fate of injected MSCs, pancreas sections were examined. The GFP labeled MSCs can be found engrafted into the pancreatic tissues (Figure 3A). The islets in the MSCs group were significantly restored compared to the control group, as shown by the pancreatic tissue immunofluorescence (Figure 3B). Under $x 400$ magnifications, 5 immunofluorescence areas were selected randomly, measured and analyzed using the Imaging Pro- 6 software. The immunofluorescence areas in the MSCs group at day 21 (following STZ injection) were significantly larger than that of the control group, while the areasremained unchanged at day 35 following STZ injection (Figure 3C).

MSCs administrationenlarged the $\operatorname{Pdx} 1+$ cell population within the islets

$\mathrm{Pdx} 1$ is an important transcription factor for the development of islet and islet function. It is only expressed in the pancreatic progenitor cells and become demolished in the mature islets. $\mathrm{Pdx} 1$ was expressed in the insulin expressing cells both in the control and MSCs injection group (Figure 4). There were 


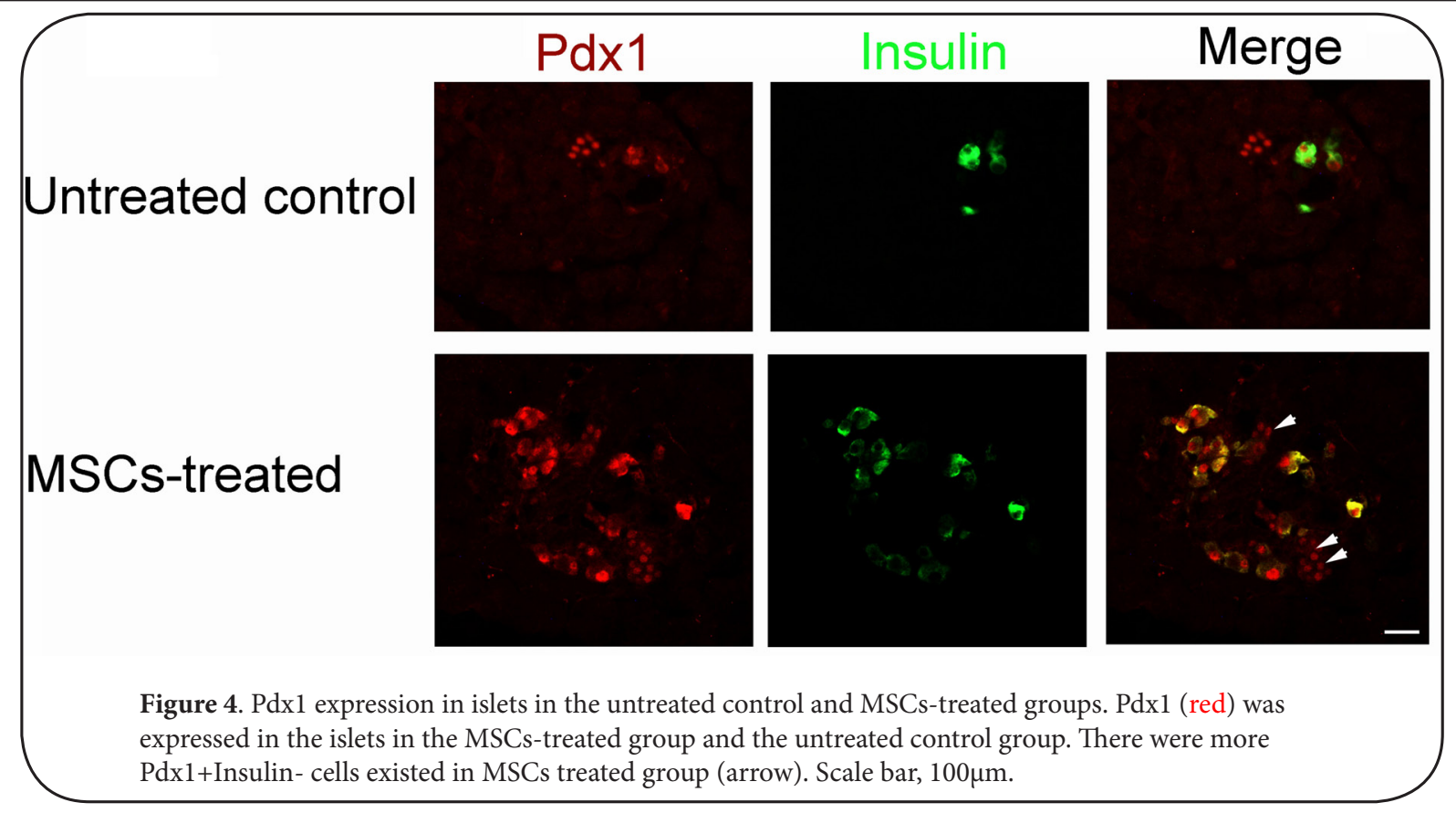

a proportion of $\mathrm{Pdx} 1^{+}$cells in the insulin cells within the islet. The numbers of $\mathrm{Pdx} 1^{+}$insulin cells were substantially greater in the MSCs treatment group than that of the control group (Figure 4, arrows and arrow heads), suggesting that Pdx1 was re-activated in the insulin cells that may contribute to islets restoration.

The imbalance between $\alpha$ and $\beta$ cells contributes the re-elevated blood glucose level

Blood glucose is mainly regulated by insulin and glucagons. After a short-term reduction of blood glucose following MSCs transplantation, glucose level re-elevated again. We hypothesized that the glucagons secreting a cellsmay also increase following the MSCs transplantation. To examine this, we compared cell numbers of glucagon secreting a cells and glucose irrelevant somatostatin secreting $\delta$-cells. We found that the numbers of glucagon-expressing cells (a cells) was greatly increased in the MSCs-treated group compared to the normal animals (Figure 5A), while the number of somatostatin expressing cells within the islets remained the same between the control and MSCs-treated group (Figure 5D). To further confirm this, we semi-quantified a cells and $\beta$ cells area by software. Data showed a cells area in the MSCs-treated group was significantly higher than that of untreated control and normal group. This indicated that MSCs administration greatly promote proliferation of a cells as well as $\beta$ cells. We also found that a cells area of control group was significantly higher in the diabetic rat groups than that of the normal group (Figure 5B). These data suggest that islet injury or $\beta$ cells destruction may lead to improper growth of a cells, while MSCs administration accelerate this process. We next quantified the ratio of a cells area to $\beta$ cells, which were dramatically higher in the MSCs treated and untreated group than that of normal group. Inmorphology, the a cells were mainly seen at the borders of islets in the normal animals, whereas the a cells were mixed with the $\beta$ cells in the untreated control and MSCs-treated group; and the a cells became predominant cell type within the islets in the MSCs-treated group (Figure 5A).

The expression of Cdk4 was upregulated in islets and INS1 cells when co-cultured with MSCs

The coculture system was used to classify the underlining mechanisms of the regeneration of $\beta$ cells. We cocultured MSCs with freshly isolated rat islets and a rat $\beta$ cells cell line INS1 cells in transwell system. After coculturingwith MSCs for 5 days, the expression of $\mathrm{Cdk} 4$ was significantly upregulated by quantitative PCR examination (Figure 6).

\section{Discussion}

The present study indicates that administration of the bone marrow derived MSCs in diabetic rats can alleviate the high blood glucose syndromes for a short period, with signs of islets regeneration. The transplantation of MSC triggere dexpression of $\mathrm{Pdx} 1$ within the islets, and co-culture of the isolated islets withMSCs also induced expression of $\mathrm{Cdk} 4$, suggesting that MSCs may assistislets regeneration. However, the glucagon secreting a cells increased significantly in the MSCs-treated group, leading to increased blood glucose level again. These results suggest that administration of undifferentiated MSCs for the treatment of diabetes needs careful consideration.

Bone marrow MSCs transplantation has been used for diabetes therapy $[13,21]$. Hessreported that bone marrow derived stem cells $\left(\mathrm{C}-\mathrm{kit}^{+}\right)$can initiate the regeneration of the endogenous islets, the donor derived endothelial cells 
Meng et al. Journal of Diabetes Research and Clinical Metabolism 2013,

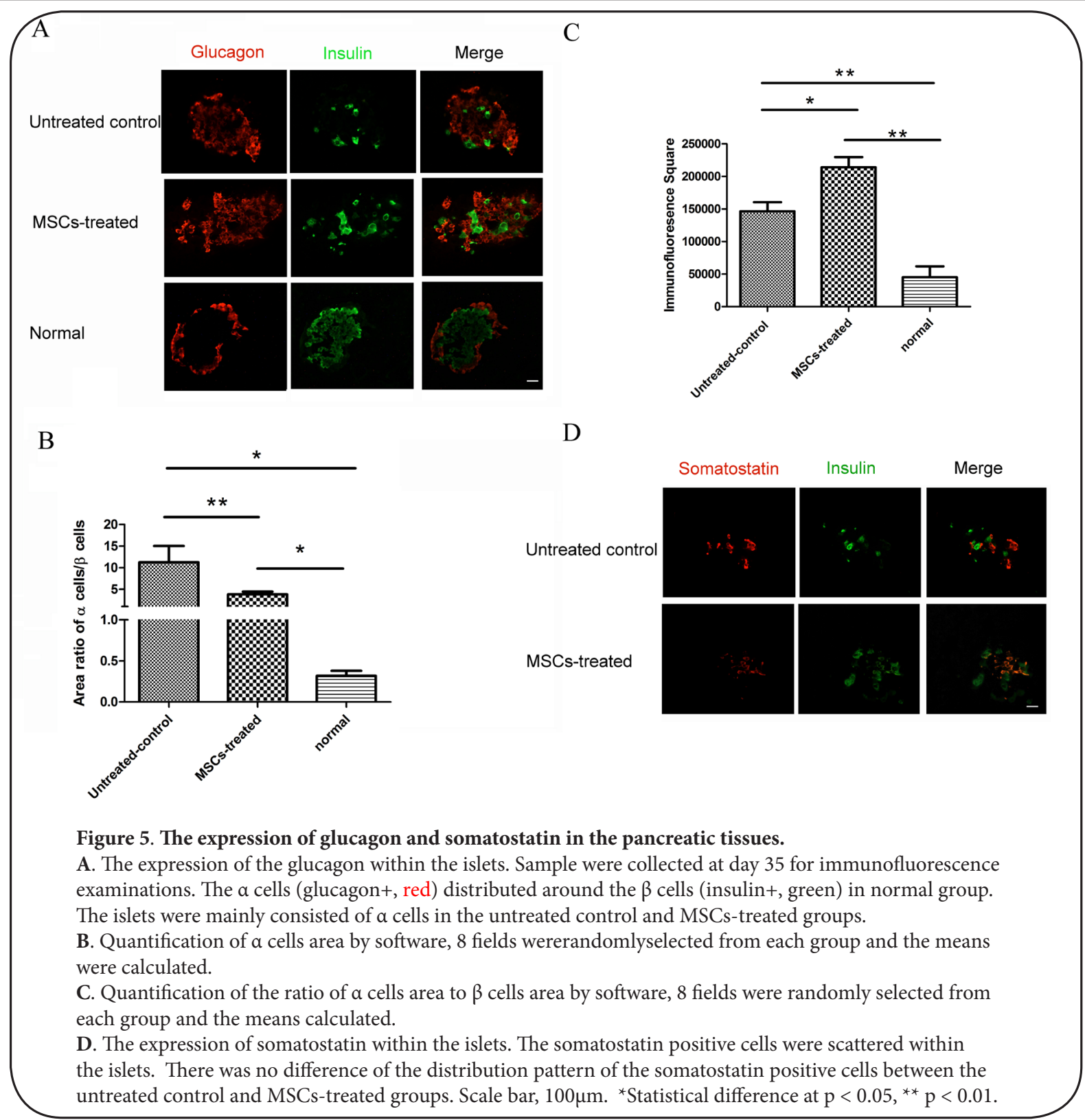

A

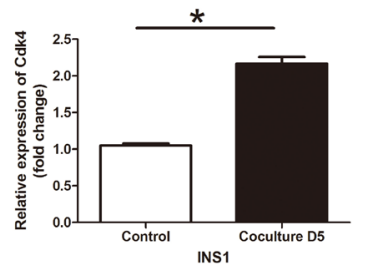

B

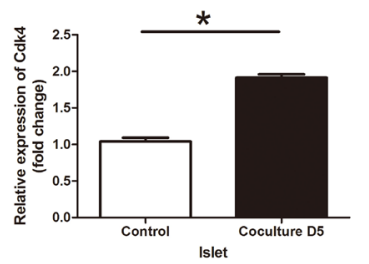

Figure 6. Cdk4 gene expression in the INS1 cells and fresh islets. After INS1 cells and islets were co-cultured with MSCs in the transwell system for 5 days, the Cdk4 mRNA level was significantly increased in both for INS1 cells (A) and islets (B). ${ }^{* *}$ Statistical difference at $\mathrm{p}<0.01$.
$\left(\mathrm{PECAM}^{+}\right)$participating the regeneration. Lee et al., [3] reported that the human MSCs could engraft into the mouse pancreas and kidney, the islet became larger after MSCs transplantation and appeared to bud off pancreatic ducts. The alleviation of the high glucose syndromes after bone marrow transplantation may be a necessary step associated with islets regeneration, which has been reported previously that administration of MSCs could reverse diabetic mice hyperglycemia for at least 2 months, accompanying with reduced albuminuriaand renal histopathologic alterations [4]. In our study, the GFP-MSCs were found in the pancreas, proving that MSCs engrafted in the pancreas. We found that the injured islets were partially restored in the MSCs-treated rats, although the size was smaller 
than the normal islets. The blood glucose level reduced for a short period ( 11 days) following MSCs administration, then elevated again. This finding is consistent with recent studied reported by Si et al., [6]. The regenerated islets may contribute to the reduction of blood glucose level, asasubstantialnumbers of Pdx $1^{+}$Insulin cells were found within the islets in both the untreated control and MSCs-treated groups. Pdx 1 is a key regulator for islet formation [10] and it been reported that the injury in the pancreas can lead to isletsregeneration accompanied by transient expression of $\mathrm{Pdx} 1$ [22]. The Pdx1 ${ }^{+}$ Insulin cells may be precursor $\beta$ cells suggested by the previous reports [23]. MSCs transplantationobviously accelerated the islets regeneration process. The role and fate of these $\mathrm{Pdx} 1^{+}$ Insulin cells still need further investigation.

The therapeuticeffect of MSCs administrationfor the treatment oftype 1 diabetes (T1D) and type 2 diabetes (T2D) was intensively studied. Substantial immunosuppressive factors like TGF- $\beta$, IL-10, HGF and chemoattractants and trophic factors like CX3CL-1,HGF, VEGFmay be produced by MSCs in vivo, which were thought to modulate the immune attack by T cell in T1D and support the survival of local existing islet $\beta$ cells $[7,24]$. In our study, we found that MSCs administration promoted regeneration of islet insulin secreting cells. However, another concern is that the uncontrolled proliferation may cause dysfunction of $\beta$ cells and lack of coordination between $\beta$, a cells or other cell types. We found that a cells numbers increased significantly in the untreated control and MSCs-treated rats than that of normal rats and the increased a cells may contribute toelevated high blood glucose levelfollowing a short periodof decline, as the production of a cells might have out-numbered the $\beta$ cells in the MSCstreated group. Moreover, the ratio of a cells to $\beta$ cells was dramatically higher in the diabetic rats than those of the normal ones, indicating that the increased number of glucagon secreting a cells may be responsible for increasing the blood glucose level in the present study. Since the MSCs implanted in the present study were undifferentiated and the local environment in the injured pancreas may not be right for insulin-producing $\beta$ cells differentiation and proliferation, the exact conditions for promoting MSCs $\beta$ cells differentiation in vivo are still unknown. Pre-programme MSCs in vitro to induce their differentiation towards to $\beta$ cells lineage may be desirable for regenerating $\beta$ cells in vivo, this will be the future research directions.

$\mathrm{Cdk} 4$ gene playsa key role of regulating islets regeneration. Lee et al., reported recently that Cdk4 stimulates the quiescent $\beta$ cells and the $\beta$ cells progenitors to proliferate [14]. Experimental evidences showed that postnatal islets grow mainly through replication of $\beta$ cells rather than differentiation from pancreatic progenitors both in human and mouse $[\mathbf{2 5 , 2 6 ]}$. It is reasonable that Cdk4 is indispensable for islet regeneration, as loss of Cdk4 expression resulted in insulin deficient diabetes [27]. Furthermore, Cdk4 together with cyclinD1 enhance $\beta$ cells proliferation by improving retinoblastoma protein phosphorylation (pRb) [15]. In this study, we found that islets co-culutured with MSCs can upregulate expression of Cdk4 in islet. This indicates Cdk4 may contribute to MSCs inducing islet regeneration. Nevertheless, how MSCs influenced Cdk4 expression in islet and INS1still need further investigation.

\section{Conclusion}

The current study found that transplantation of allogenic MSCs in diabetic rats can reduce the blood glucose level in a short period, and apparently promoted the regeneration of the injured islets. However, the transplantation strategies need to be optimized to improve the survival of the transplanted MSCs in vivo and suppress a cell abnormal proliferation.

\section{Competing interests}

The authors declare that they have no competing interests.

\section{Acknowledgement}

This study was supported by grants the National Key Basic Research and Development of China (973Program, 2012CB518100) and National Natural Science Foundation of China (81150018).

\section{Publication history}

Received: 02-Dec-2012 Revised: 12-Jan-2013

Re-Revised: 15-Jan-2013 Accepted: 19-Jan-2013

Published: 06-Feb-2013

\section{References}

1. Phinney DG and Prockop DJ: Concise review: mesenchymal stem/ multipotent stromal cells: the state of transdifferentiation and modes of tissue repair--current views. Stem Cells 2007, 25:2896-902. | Article PubMed

2. Li T and Wu Y: Paracrine molecules of mesenchymal stem cells for hematopoietic stem cell niche. Bone Marrow Res 2011, 2011:353878. | Article | PubMed Abstract | PubMed Full Text

3. Lee RH, Seo MJ, Reger RL, Spees JL, Pulin AA, Olson SD and Prockop DJ: Multipotent stromal cells from human marrow home to and promote repair of pancreatic islets and renal glomeruli in diabetic NOD/scid mice. Proc Natl Acad Sci U S A 2006, 103:17438-43. | Article | PubMed Abstract | PubMed Full Text

4. Ezquer FE, Ezquer ME, Parrau DB, Carpio D, Yanez AJ, Conget PA: Systemic administration of multipotent mesenchymal stromal cells reverts hyperglycemia and prevents nephropathy in type 1 diabetic mice. Biol Blood Marrow Transplant 2008, 14:631-640. | Article | PubMed

5. Pittenger MF, Mackay AM, Beck SC, Jaiswal RK, Douglas R, Mosca JD, Moorman MA, Simonetti DW, Craig S, Marshak DR: Multilineage potential of adult human mesenchymal stem cells. Science 1999, 284:143-147. | Article | PubMed

6. Si Y, Zhao Y, Hao H, Liu J, Guo Y, Mu Y, Shen J, Cheng Y, Fu X, Han W: Infusion of mesenchymal stem cells ameliorates hyperglycemia in type 2 diabetic rats: identification of a novel role in improving insulin sensitivity. Diabetes 2012, 61:1616-1625. | Article | PubMed

7. Davis NE, Hamilton D, Fontaine MJ: Harnessing the immunomodulatory and tissue repair properties of mesenchymal stem cells to restore beta cell function. Curr Diab Rep 2012, 12:612-622. | Article I PubMed

8. Brissova M, Fowler MJ, Nicholson WE, Chu A, Hirshberg B, Harlan DM, Powers AC: Assessment of human pancreatic islet architecture and composition by laser scanning confocal microscopy. J Histochem Cytochem 2005, 53:1087-1097. I Article I PubMed

9. Ferber S, Halkin A, Cohen H, Ber I, Einav Y, Goldberg I, Barshack I, Seijffers 
Meng et al. Journal of Diabetes Research and Clinical Metabolism 2013, http://www.hoajonline.com/journals/pdf/2050-0866-2-7.pdf

R, Kopolovic J, Kaiser N, Karasik A: Pancreatic and duodenal homeobox gene 1 induces expression of insulin genes in liver and ameliorates streptozotocin-induced hyperglycemia. Nat Med 2000, 6:568-572. Article I PubMed

10. Oliver-Krasinski JM, Kasner MT, Yang J, Crutchlow MF, Rustgi AK, Kaestner $\mathrm{KH}$, Stoffers DA: The diabetes gene Pdx1 regulates the transcriptional network of pancreatic endocrine progenitor cells in mice. J Clin Invest 2009, 119:1888-1898. | Article | PubMed Abstract | PubMed Full Text

11. Oliver-Krasinski JM, Stoffers DA: On the origin of the beta cell. Genes Dev 2008, 22:1998-2021. | Article | PubMed Abstract | PubMed Full Text

12. Xu X, D'Hoker J, Stange G, Bonne S, De Leu N, Xiao X, Van de Casteele M, Mellitzer G, Ling Z, Pipeleers D, Bouwens L, Scharfmann R, Gradwohl G, Heimberg $\mathrm{H}$ : Beta cells can be generated from endogenous progenitors in injured adult mouse pancreas. Cell 2008, 132:197-207. | Article | PubMed

13. Hess D, Li L, Martin M, Sakano S, Hill D, Strutt B, Thyssen S, Gray $\mathrm{DA}, \mathrm{Bhatia} \mathrm{M}$ : Bone marrow-derived stem cells initiate pancreatic regeneration. Nat Biotechnol 2003, 21:763-770. | Article | PubMed

14. Lee JH, Jo J, Hardikar AA, Periwal V, Rane SG: Cdk4 regulates recruitment of quiescent beta-cells and ductal epithelial progenitors to reconstitute beta-cell mass. PLoS One 2010, 5:e8653. | Article | PubMed Abstract | PubMed Full Text

15. Cozar-Castellano I, Takane KK, Bottino R, Balamurugan AN, Stewart AF: Induction of beta-cell proliferation and retinoblastoma protein phosphorylation in rat and human islets using adenovirus-mediated transfer of cyclin-dependent kinase-4 and cyclin D1. Diabetes 2004, 53:149-159. | Article | PubMed

16. Krishnamurthy J, Ramsey MR, Ligon KL, Torrice C, Koh A, Bonner-Weir $S$, Sharpless NE: p16INK4a induces an age-dependent decline in islet regenerative potential. Nature 2006, 443:453-457. | Article | PubMed

17. Kim NN, Stankovic M, Cushman TT, Goldstein I, Munarriz R, Traish AM: Streptozotocin-induced diabetes in the rat is associated with changes in vaginal hemodynamics, morphology and biochemical markers. $B M C$ Physiol 2006, 6:4. | Article | PubMed Abstract | PubMed Full Text

18. Akbarzadeh A, Norouzian D, Mehrabi MR, Jamshidi S, Farhangi A, Verdi AA, Mofidian SM, Rad BL: Induction of diabetes by Streptozotocin in rats. Indian J Clin Biochem 2007, 22:60-64. | Article | PubMed Abstract | PubMed Full Text

19. Tiscornia G, Singer O, Verma IM: Production and purification of lentiviral vectors. Nat Protoc 2006, 1:241-245. | Article | PubMed

20. Carter JD, Dula SB, Corbin KL, Wu R, Nunemaker CS: A practical guide to rodent islet isolation and assessment. Biol Proced Online 2009, 11:3-31. | Article | PubMed Abstract | PubMed Full Text

21. lanus A, Holz GG, Theise ND, Hussain MA: In vivo derivation of glucosecompetent pancreatic endocrine cells from bone marrow without evidence of cell fusion. J Clin Invest 2003, 111:843-850. | Article | PubMed Abstract | PubMed Full Text

22. Chase HP, MacKenzie TA, Burdick J, Fiallo-Scharer R, Walravens $P$, Klingensmith $G$, Rewers $M$ : Redefining the clinical remission period in children with type 1 diabetes. Pediatr Diabetes 2004, 5:16-19. | Article I PubMed

23. Li WC, Rukstalis JM, Nishimura W, Tchipashvili V, Habener JF, Sharma A, Bonner-Weir S: Activation of pancreatic-duct-derived progenitor cells during pancreas regeneration in adult rats. J Cell Sci 2010, 123:27922802. | Article | PubMed Abstract | PubMed Full Text

24. Davis NE, Beenken-Rothkopf LN, Mirsoian A, Kojic N, Kaplan DL, Barron $A E$, Fontaine $M J$ : Enhanced function of pancreatic islets co-encapsulated with ECM proteins and mesenchymal stromal cells in a silk hydrogel. Biomaterials 2012, 33:6691-6697. | Article | PubMed

25. Meier JJ, Butler AE, Saisho Y, Monchamp T, Galasso R, Bhushan A, Rizza RA, Butler PC: Beta-cell replication is the primary mechanism subserving the postnatal expansion of beta-cell mass in humans. Diabetes 2008, 57:1584-1594. | Article | PubMed

26. Dor Y, Brown J, Martinez OI, Melton DA: Adult pancreatic beta-cells are formed by self-duplication rather than stem-cell differentiation. Nature 2004, 429:41-46. | Article | PubMed
27. Rane SG, Dubus P, Mettus RV, Galbreath EJ, Boden G, Reddy EP, Barbacid M: Loss of Cdk4 expression causes insulin-deficient diabetes and Cdk4 activation results in beta-islet cell hyperplasia. Nat Genet 1999, 22:4452. | Article | PubMed

\section{Citation:}

Meng F-B, Liu X-Y, Li H-T, Pang X-N and Li G:

Regulation of blood glucose by administration of allogenic bone marrow derived mesenchymal stem cells into diabetic rats through modulating regeneration of both $\boldsymbol{\alpha}$ and $\boldsymbol{\beta}$ islet cells. Journal of Diabetes Research and Clinical Metabolism 2013, 2:7. http://dx.doi.org/10.7243/2050-0866-2-7 